\title{
HUBUNGAN TINGKAT PENGETAHUAN DENGAN SIKAP IBU DALAM MOBILISASI DINI PASCA SECTIO CESAREAN
}

\author{
Ni Ketut Citrawati ${ }^{1}$ Ni Luh Gede Rika Rahayu ${ }^{2}$, Niken Ayu Merna Eka Sari ${ }^{3}$ \\ ${ }^{1,2,3}$ STIKES Wira Medika Bali \\ citrabali@ymail.com
}

\author{
Diterima: April 2021, Diterbitkan: Juni 2021
}

\begin{abstract}
ABSTRAK
Pendahuluan : Sectio cesarean merupakan tindakan pembedahan yang dilakukan untuk melahirkan janin melalui sayatan dinding abdomen dan uterus. Ibu pasca sectio cesarean diharuskan untuk melakukan mobilisasi dini karena memberi manfaat yang besar yaitu mencegah tombosis pada pembuluh tungkai dan membantu kemajuan ibu dari ketergantungan sakit menjadi sehat. 5 orang ibu pasca sectio cesarean 3 diantaranya mengatakan takut melakukan mobilisasi dini dengan alasan ketidaktahuan dan kekhawatiran. Tujuan dari penelitian ini adalah untuk mengetahui hubungan tingkat pengetahuan dengan sikap ibu dalam mobilisasi dini pasca sectio cesarean di Ruang Dara RSUD Wangaya Denpasar. Metode: Penelitian ini merupakan penelitian non-eksperimental dengan metode penelitian korelasional. Sampel yang digunakan adalah 35 responden dengan teknik Purposive Sampling. Hasil: Penelitian ini menunjukan sebagian besar responden memiliki tingkat pengetahuan yang baik yaitu 16 responden (45,7\%), cukup 14 responden $(40,0 \%)$ dan kurang 4 responden $(14,3 \%)$. Hasil Analisa data dengan rank spearman diperoleh hasil $p=0,000$. Karena nilai $\mathrm{p}<\alpha(0,05)$. Maka dapat disimpulkan ada hubungan antara tingkat pengetahuan dengan sikap ibu dalam mobilisasi dini pasca sectio cesarean di Ruang Dara RSUD Wangaya Denpasar. Diskusi: Saran khususnya ibu post sectio cesarean untuk segera melakukan mobilisasi dini mengingat pentingnya mobilisasi dini pasca sectio cesarean.
\end{abstract}

Kata kunci : Tingkat Pengetahuan, Sikap, Mobilisasi Dini Pasca Section Cesarean.

\begin{abstract}
Introduction: Cesarean Section is a surgical operation for delivering a child by cutting through the wall of abdomen and uterus. Mothers after cesarean section must do early mobilization because will get many benefit, namely preventing tombosis in the leg vessels and helping the mother progress from sick dependence to health. 5 mothers after cesarean section 3 of them said they were afraid to do early mobilization due to ignorance and concern. The purpose of this study was to determine the correlation between the level of knowledge and mother's attitude in early mobilization post cesarean section in the Dara Room of RSUD Wangaya Denpasar. Method: This research is a non-experimental study with a correlational research method. The sample in this study was 35 respondents with purposive sampling technique. Result: The results showed that most respondents had a good level of knowledge, namely 16 respondents (45.7\%), 14 respondents (40.0\%) and less 4 respondents (14.3\%). Results of data analysis with Spearman rank results obtained $p=0.000$. Because the $p$ value $<\alpha(0.05)$. So it can be concluded that there is correlation between the level of knowledge and mother's attitude in early mobilization post sectio cesarean in the Dara Room of RSUD Wangaya Denpasar. Discussion: Suggestions, especially mothers after cesarean section to immediately carry out early mobilization considering the importance of early mobilization after cesarean section.
\end{abstract}

Keywords: Level of Knowledge, Attitude, Early Mobilization After Cesarean Section. 


\section{PENDAHULUAN}

AKI merupakan indicator untuk melihat derajat kesehatan perempuan dan menjadi salah satu indeks pembangunan maupun indeks kualitas hidup (Susiana, 2019). Hingga di tahun 2019 AKI di Indonesia masih tinggi yaitu 305 per 100.000 kelahiran hidup menurut Ketua Komite Ilmiah International Conference on Indonesia Family Planning and Reproductive Health (ICIFPRH) dalam Susiana (2019).

Program Sustainable Development Goals (SDGs) yang diluncurkan di tahun 2016, target AKI adalah 70 per 100.000 kelahiran hidup pada tahun 2030. Sehingga diperlukan kerja keras dan kesungguhan untuk mencapai target tersebut. Penyebab kematian ibu menurut data WHO (World Health Organization) kematian ibu terjadi akibat komplikasi saat dan pasca kehamilan. Adapun jenis-jenis komplikasi yang menyebabkan mayoritas kematian ibu sekitar $75 \%$ disebabkan oleh perdarahan, infeksi, tekanan darah tinggi saat kehamilan, komplikasi persalinan dan aborsi yang tidak aman. Sedangkan sebagian besar dari kematian ibu di sebabkan kerena perdarahan, infeksi dan preeklamsia selama persalinan.

Persalinan dibedakan menjadi dua, persalinan spontan dan persalinan melalui bantuan yang dikenal dengan operasi sectio cesarean (Nurzaid, 2019). Persalinan sectio cesarean yaitu suatu cara melahirkan janin dengan membuat sayatan pada dinding uterus melalui dinding depan perut (Rottie \& Saragih, 2019). Terjadi peningkatan persalinan sectio cesarean di dunia dan melebihi batas kisaran 10\%-15\% yang direkomendasikan World Health Organization (WHO) dalam upaya penyelamatan nyawa ibu dan bayi. Amerika Latin dan wilayah Karibia menjadi penyumbang angka metode sesar tertinggi yaitu 40,5 persen, diikuti oleh Eropa (25\%), Asia (19,2\%) dan Afrika (7,3\%) (Sulistianingsih \& Bantas, 2019). Berdasarkan hasil Riset Kesehatan Dasar (Riskesdas) tahun 2018, prevalensi tindakan sesar pada persalinan di Indonesia adalah 17,6 persen, tertinggi berada di wilayah DKI Jakarta $(31,3 \%)$ dan terendah di Papua (6,7\%) (Riskesdas, 2018). Dari total persalinan di Bali, berdasarkan data Sistem Informasi Rumah Sakit (SIRS) Dinas Kesehatan Provinsi Bali, terdapat 21.965 kasus pada tahun 2015, sekitar 58,5 $\%$ dilakukan melalui operasi sectio cesarean. Selama tahun 2015, kasus kelahiran melalui sectio cesarean terbanyak terjadi di Kota Denpasar (4.915 kasus). Kemudian disusul oleh Kabupaten Gianyar (2.567 kasus), Kabupaten Tabanan (1.061 kasus), Kabupaten Badung (1.045 kasus), Kabupaten Buleleng (967 kasus), Kabupaten Klungkung (631 kasus), Kabupaten Jembrana (616 kasus), Kabupaten Bangli (592 kasus), dan Kabupaten Karangasem (513 kasus) (Tribun, 2017).

Persalinan sectio caesarean dapat mengakibatkan resiko terjadinya infeksi, karena infeksi merupakan salah satu penyebab utama kematian ibu. Selain itu infeksi merupakan komplikasi yang banyak terjadi pada ibu pasca sectio cesarean akibat luka operasi dengan angka kejadian 25 kali lebih tinggi dibandingkan kejadian infeksi pada persalinan pervaginam (Manggala et al., 2013). Upaya yang dapat dilakukan untuk memperkecil terjadinya resiko atau mencegah terjadinya komplikasi adalah dengan melakukan mobilisasi dini (Manggala et al., 2013). Mobilisasi dini harus dilakukan untuk mencegah terjadinya perdarahan abnormal serta mempercepat penyembuhan luka (Nurzaid, 2019). Berdasarkan hasil penelitian yang dilakukan oleh Rottie J, Erlita Saragih R, tahun 2019 mengungkapkan bahwa seluruh responden yang melakukan mobilisasi dini sebanyak 21 pasien. Dari hasil penelitian terlihat bahwa lebih banyak responden yang melakukan mobilisasi dini dengan penyembuhan luka post operasi sectio cesarean membaik. Dari hasil analisis disimpulkan bahwa ada pengaruh mobilisasi dini terhadap penyembuhan luka post sectio cesarean di Irina D Bawah RSUP Prof. Dr. R. D. Kandou Manado. Rendahnya mobilisasi dini pada pasien 
setelah operasi dikarenakan pasien merasa takut untuk bergerak setelah pembedahan. Selain itu faktor yang menghambat dikarenakan rasa nyeri yang dirasakan, serta kekhawatiran kalau tubuh yang digerakkan pada posisi tertentu pasca operasi akan mempengaruhi luka operasi yang belum sembuh. Kekhawatiran tersebut dikarenakan kurangnya pengetahuan pasien tentang manfaat dari mobilisasi dini dan masih kurangnya pengetahuan masyarakat di bidang kesehatan (Nurzaid, 2019).

Berdasarkan studi pendahuluan yang dilakukan oleh 5 orang ibu pasca sectio cesarean 3 diantaranya mengatakan takut melakukan mobilisasi dini dengan alasan ketidaktahuan dan kekhawatiran. Hal ini terjadi karena pengetahuan ibu yang beranggapan bahwa ibu merasa khawatir terhadap luka jahitan, jika melakukan gerakan mempengaruhi luka operasi dan terasa nyeri. Selain itu dilakukan wawancara juga bersama salah satu bidan di ruangan mengatakan hampir seluruh pasien pasca operasi mengatakan takut untuk melakukan mobilisasi dini karena merasa khawatir dan merasakan nyeri serta minimnya pengetahuan masyarakat terhadap pentingnya mobilisasi dini.

\section{METODE PENELITIAN}

Penelitian ini merupakan penelitian noneksperimental dengan metode penelitian korelasional. Pendekatan yang digunakan pada penelitian ini yaitu pendekatan cross sectional. Penelitian ini dilakukan di Ruang Dara RSUD Wangaya Denpasar pada tanggal 15 Desember 2020 -31 Januari 2021. Populasi pada penelitian ini adalah 39 responden yang didapat dari rata-rata jumlah ibu yang menjalani sectio cesarean di Ruang Dara RSUD Wangaya Denpasar dari bulan Juni - Agustus tahun 2020 yang berjumlah 117. Jumlah sampel penelitian ini adalah 35 responden yang sesuai dengan kriteria inklusi dan kriteria eksklusi. Teknik pengambilan sampel yang digunakan dalam penelitian ini adalah purposive sampling. Kriteria inklusi dalam penelitian ini yaitu : pasien yang bersedia sebagai responden, ibu pasca SC berusia 20-45 tahun, ibu yang pertama kali menjalani tindakan operasi sectio cesarean, ibu post operasi sectio cesarean hari 1-hari ke 2, ibu dengan masalah persalinan maupun letak janin yang diharuskan melakukan operasi sectio cesarean. Kriteria eksklusi dalam penelitian ini yaitu: ibu post SC dengan indikasi preeklamsi berat, (PEB), dan penyakit jantung serta indikasi lain yang mengharuskan ibu dipasangkan alat-alat yang tidak memungkinkan untuk mobilisasi dini. Pengumpulan data menggunakan kuesioner melalui google form. Kuesioner tingkat pengetahuan ibu tentang mobilisasi dini telah dilakukan uji validitas dengan rentang nilai $0,570-0,888$ dan reliabilitas sebesar 0,933 yang artinya kuesioner tingkat pengetahuan ibu tentang mobilisasi dini sudah valid atau reliabel sedangkan Kuesioner sikap ibu dalam mobilisasi dini dilakukan uji validitas dengan korelasi sebesar 0,96 dan reliabilitas dengan nilai 0,871 yang artinya kuesioner sikap ibu dalam mobilisasi dini sudah valid atau reliabel. Adapun analisa data yang dilakukan dalam penelitian ini yaitu: analisis univariat dan analisis bivariat. Analisis univariat digunakan untuk menggambarkan distribusi frekuensi responden berdasarkan umur, pendidikan, pekerjaan, riwayat sectio cesarean dan informasi mobilisasi dini. Sedangkan analisi bivariat digunakan untuk menguji ada tidaknya hubungan antara variable tingkat pengetahuan dan sikap dalam mobilisasi dini. Data dianalisis kemudian hasilnya disajikan dalam bentuk narasi dan tabel distribusi frekuensi.

\section{HASIL DAN PEMBAHASAN}

Berdasarkan tabel 1 diatas, didapatkan bahwa dari 35 responden didapatkan data sebagian besar yaitu berusia 17-25 tahun sebanyak 21 responden $(60,0 \%)$, dari 35 responden sebagian besar berpendidikan terakhir perguruan tinggi sebanyak 24 responden $(68,6 \%)$, dari 35 responden sebagian besar bekerja sebagai pegawai swasta yaitu sebanyak 17 
responden $(48,6 \%)$, dari 35 responden didapatkan bahwa semuanya yaitu 35 responden $(100 \%)$ tidak pernah memiliki riwayat sectio caecarea sebelumnya, dan dari 35 responden didapatkan bahwa semuanya yaitu 35 responden (100\%) pernah memperoleh informasi tentang mobilisasi dini pasca sectio cesarean.

Tabel 1

Distribusi Frekuensi Karakteristik Ibu Pasca Sectio Cesarean Berdasarkan Usia. Pendidika, Pekerjaan, Riwayat SC Sebelumnya, dan Informasi Mobilisasi Dini di Ruang Dara RSUD Wangaya Denpasar

\begin{tabular}{|c|c|c|c|c|}
\hline No & $\begin{array}{c}\text { Karakteris } \\
\text { tik }\end{array}$ & Jumlah & $\begin{array}{c}\text { Frekuensi } \\
\text { (f) }\end{array}$ & $\begin{array}{c}\text { Presentasi } \\
(\%)\end{array}$ \\
\hline \multirow[t]{4}{*}{1.} & Usia & $17-25$ tahun & 21 & 60,0 \\
\hline & & 26-35 tahun & 13 & 37,1 \\
\hline & & 36-45 tahun & 1 & 2,9 \\
\hline & & Jumlah & 35 & 100 \\
\hline \multirow[t]{5}{*}{2.} & Pendidikan & SD & 0 & 0,0 \\
\hline & & SMP & 0 & 0,0 \\
\hline & & SMA & 11 & 31,4 \\
\hline & & $\begin{array}{c}\text { Perguruan } \\
\text { Tinggi }\end{array}$ & 24 & 68,6 \\
\hline & & Jumlah & 35 & 100 \\
\hline \multirow[t]{5}{*}{3.} & Pekerjaan & PNS & 2 & 5,7 \\
\hline & & $\begin{array}{c}\text { Pegawai } \\
\text { swasta }\end{array}$ & 17 & 48,6 \\
\hline & & IRT & 9 & 25,7 \\
\hline & & Lainnya & 7 & 20,0 \\
\hline & & Jumlah & 35 & 100 \\
\hline \multirow[t]{3}{*}{4.} & $\begin{array}{l}\text { Riwayat SC } \\
\text { sebelumnya }\end{array}$ & Pernah & 0 & 0 \\
\hline & & Tidak pernah & 35 & 100 \\
\hline & & Jumlah & 35 & 100 \\
\hline \multirow[t]{3}{*}{5.} & $\begin{array}{c}\text { Informasi } \\
\text { Mobilisasi } \\
\text { Dini }\end{array}$ & $\mathrm{Ya}$ & 35 & 100 \\
\hline & & Tidak & 0 & 0 \\
\hline & & Jumlah & 35 & 100 \\
\hline
\end{tabular}

Tabel 2

Distribusi Frekuensi Tingkat Pengetahuan Ibu Pasca Sectio Cesarean Tentang Mobilisasi Dini di Ruang Dara RSUD

\begin{tabular}{cccc}
\hline No & $\begin{array}{c}\text { Tingkat } \\
\text { Pengetahuan }\end{array}$ & $\begin{array}{c}\text { Frekuensi } \\
(\mathbf{f})\end{array}$ & Persentase (\%) \\
\hline 1 & Kurang & 5 & 14,3 \\
\hline 2 & Cukup & 14 & 40,0 \\
\hline 3 & Baik & 16 & 45,7 \\
\hline & Jumlah & 35 & 100 \\
\hline
\end{tabular}

Berdasarkan tabel 2 diatas, tingkat pengetahuan dari 35 responden didapatkan sebagian besar yaitu 16 responden $(45,7 \%)$ memiliki tingkat pengetahuan yang baik tentang mobilisasi dini.

Tabel 3

Distribusi Frekuensi Sikap Ibu Pasca Sectio Cesarean Dalam Mobilisasi Dini di Ruang Dara RSUD Wangaya Denpasar

\begin{tabular}{cccc}
\hline No & $\begin{array}{c}\text { Sikap Dalam } \\
\text { Mobilisasi } \\
\text { Dini }\end{array}$ & $\begin{array}{c}\text { Frekuensi } \\
(\mathbf{f})\end{array}$ & $\begin{array}{c}\text { Persentase } \\
(\boldsymbol{\%})\end{array}$ \\
\hline 1 & Kurang & 3 & 8,6 \\
\hline 2 & Cukup & 15 & 42,8 \\
\hline 3 & Baik & 17 & 48,6 \\
\hline & Jumlah & 35 & 100 \\
\hline
\end{tabular}

Berdasarkan table 4, dapat dijelaskan bahwa responden yang memiliki tingkat pengetahuan yang baik sebagian besar memiliki sikap yang baik dalam mobilisasi dini pasca section cesarean dengan persentase $34,3 \%$. Berdasarkan uji rank spearman dan diperoleh nilai $\mathrm{p}=0,000$. Karena nilai $\mathrm{p}<\alpha(0,05)$, maka $\mathrm{H}_{0}$ ditolak. Hal ini berarti bahwa ada hubungan tingkat pengetahuan dengan sikap ibu dalam mobilisasi dini pasca sectio cesarean di Ruang Dara RSUD Wangaya Denpasar. Berdasarkan tabel diatas dapat dilihat nilai $r$ hitung sebesar 0,609 nilai tersebut menunjukkan korelasi yang kuat antara variabel tingkat pengetahuan dengan sikap ibu dalam mobilisasi dini pasca sectio cesarean. Nilai koefisien korelasi bertanda positif ini menujukkan bahwa semakin baik tingkat pengetahuan maka semakin baik juga sikap ibu dalam mobilisasi dini pasca sectio cesarean di Ruang Dara RSUD Wangaya Denpasar.

\section{PEMBAHASAN}

Hasil penelitian menunjukan responden yang memiliki tingkat pengetahuan yang baik sebagian besar memiliki sikap yang baik dalam mobilisasi dini pasca section cesarean dengan persentase 34,3\%. Berdasarkan uji rank spearman dan diperoleh nilai $\mathrm{p}=0,000$. Karena nilai $\mathrm{p}<\alpha$ $(0,05)$, maka $\mathrm{H}_{0}$ ditolak. Hal ini berarti bahwa ada hubungan tingkat pengetahuan 
Tabel 4

Analisis Bivariat Hubungan Tingkat Pengetahuan Dengan Sikap Ibu Dalam Mobilisasi Dini Pasca Sectio Cesarean di Ruang Dara

RSUD Wangaya Denpasar

\begin{tabular}{|c|c|c|c|c|c|c|c|c|c|c|}
\hline \multirow{3}{*}{$\begin{array}{c}\text { Tingkat } \\
\text { Pengetahuan }\end{array}$} & \multicolumn{6}{|c|}{ Sikap } & \multicolumn{2}{|c|}{ Jumlah } & \multirow[t]{3}{*}{$P$ value } & \multirow[t]{3}{*}{ R Tabe } \\
\hline & \multicolumn{2}{|c|}{ Kurang } & \multicolumn{2}{|c|}{ Cukup } & \multicolumn{2}{|c|}{ Baik } & & & & \\
\hline & $\mathbf{F}$ & $\%$ & $\mathbf{F}$ & $\%$ & $\mathbf{F}$ & $\%$ & $\mathbf{F}$ & $\%$ & & \\
\hline Kurang & 3 & 8,6 & 2 & 5,7 & 0 & 0,0 & 5 & 14,3 & 0.000 & 0,609 \\
\hline Cukup & 0 & 0,0 & 9 & 25,7 & 5 & 14,3 & 14 & 40,0 & & \\
\hline Baik & 0 & 0,0 & 4 & 11,4 & 12 & 34,3 & 16 & 45,7 & & \\
\hline Jumlah & 3 & 8,6 & 15 & 42,8 & 17 & 48,6 & 35 & 100 & & \\
\hline
\end{tabular}

dengan sikap ibu dalam mobilisasi dini pasca sectio cesarean di Ruang Dara RSUD Wangaya Denpasar. Berdasarkan tabel diatas dapat dilihat nilai $\mathrm{r}$ hitung sebesar 0,609 nilai tersebut menunjukkan korelasi yang kuat antara variabel tingkat pengetahuan dengan sikap ibu dalam mobilisasi dini pasca sectio cesarean. Nilai koefisien korelasi bertanda positif, ini menujukkan bahwa semakin baik tingkat pengetahuan maka semakin baik juga sikap ibu dalam mobilisasi dini pasca sectio cesarean di Ruang Dara RSUD Wangaya Denpasar.

Hal ini sejalan dengan Ade Nur (2017) di RSU Bahteramas Provinsi Sulawesi Tenggara menyebutkan dari 42 responden tingkat pengetahuan ibu tentang mobilisasi dini sebagian besar atau sebanyak 20 responden $(47,62 \%)$ dengan kategori tingkat pengetahuan baik. Cukup sebanyak 15 responden $(35,71 \%)$ dan kurang sebanyak 7 responden $(16,67 \%)$. Menurut teori Mubarak (2013) faktor yang memperngaruhi tingkat pengetahuan adalah pendidikan, pekerjaan, umur, minat, pengalaman, kebudayaan lingkungan sekitar dan informasi. Menurut peneliti tingkat pengetahuan tentang mobilisasi dini pada ibu pasca SC di Ruang Dara RSUD Wangaya Denpasar memiliki pengetahuan yang baik dikarenakan keseluruhan responden mendapatkan informasi terkait mobilisasi dini dari bidan, selain itu usia ibu yang produktif sehingga baik untuk menerima informasi, sebagian besar bekerja sebagai pegawai swasta yang lebih banyak berinteraksi sehingga informasi lebih mudah didapat dan pendidikan terakhir ibu yang sebagian besar adalah perguruan tinggi sehingga lebih besar pemahaman dan lebih mudah menerima informasi dari bidan terkait mobilisasi dini pasca sectio cesarean.

Pada sikap ibu dalam mobilisasi dini juga sejalan dengan Ade Nur (2017) di RSU Bahteramas Provinsi Sulawesi Tenggara yaitu dari 42 responden terdapat 23 orang $(54,76 \%)$ yang memiliki sikap positif dan hanya 19 orang $(45,24 \%)$ yang memiliki sikap negative dalam mobilisasi dini. Menurut peneliti Suryani Hartati (2013) tentang faktor - faktor yang mempengaruhi ibu post SC untuk melakukan mobilisasi dini di RSCM adalah pemberian informasi, tingkat pengetahuan dan motivasi.

Menurut peneliti sikap ibu dalam mobilisasi dini pasca SC di Ruang Dara RSUD Wangaya Denpasar secara umum memiliki sikap yang baik dikarenakan tingkat pengetahuan responden yang baik, dan informasi yang didapatkan. Semakin tinggi tingkat pengetahuan ibu post sectio cesarean tentang mobilisasi dini, maka semakin terampil ibu tersebut dalam melakukan mobilisasi dini, pengetahuan ibu yang baik karena memiliki pengetahuan yang luas sehingga baik pula sikap ibu dalam mobilisasi dini untuk dapat meningkatkan kesehatannya serta keseluruhan responden di Ruang Dara RSUD Wangaya Denpasar mendapatkan informasi terkait mobilisasi dini dari bidan.

Hubungan tingkat pengetahuan dengan sikap ibu dalam mobilisasi dini sejalan dengan Ade Nur (2017) dengan nilai 
signifikansi $\mathrm{p}=0,003$ nilai ini lebih kecil dari level of significance $(\alpha)$ sebesar 0,05 . Ini berarti ada hubungan bermakna antara pengetahuan dengan sikap ibu post SC dalam mobilisasi dini di RSU Bahteramas Provinsi Sulawesi Tenggara. Penelitian juga sejalan dengan Aisyah \& Budi (2011) dimana hasil penelitian didapatkan responden berpengetahuan baik seluruhnya melakukan tindakan mobilisasi dini yaitu 15 (100\%). Responden berpengetahuan cukup lebih dari sebagian melakukan tindakan mobilisasi dini yaitu 2 $(66,7 \%)$. Sedangkan pengetahuan kurang sebagian melakukan tindakan mobilisasi dini yaitu $1(50 \%)$ responden. Kesimpulan adalah terdapat hubungan antara pengetahuan tentang mobilisasi dini dengan tindakan mobilisasi dini pada ibu nifas 1 hari post sectio cesarean.

Berdasarkan analisa peneliti tingkat pengetahuan sebagian besar memiliki sikap yang baik dalam mobilisasi dini pasca section cesarean dengan persentase $34,3 \%$ dikarenakan dipengaruhi oleh tingkat pendidikan, keseluruhan responden mendapatkan informasi terkait mobilisasi dini dari bidan, selain itu usia ibu yang produktif sehingga baik untuk menerima informasi, sebagian besar bekerja sebagai pegawai swasta yang lebih banyak berinteraksi sehingga informasi lebih mudah didapat dan pendidikan terakhir ibu yang sebagian besar adalah perguruan tinggi sehingga lebih besar pemahaman dan lebih mudah menerima informasi dari bidan terkait mobilisasi dini pasca sectio caesarea Sehingga tingkat pengetahuan tentang mobilisasi dini yang baik berdampak baik juga terhadap sikap ibu dalam mobolisasi dini. Sedangkan pada tingkat pendidikan yang rendah interaksi tersebut akan berkurang, informasi yang didapatkan juga berkurang. Jadi semakin tinggi pendidikan seseorang semakin mudah menerima informasi dan semakin banyak pula pengetahuan yang dimiliki.

\section{SIMPULAN}

Tingkat pengetahuan tentang mobilisasi dini pada ibu pasca sectio cesarean di Ruang Dara RSUD Wangaya Denpasar sebagian besar yaitu 16 responden $(45,7 \%)$ memiliki tingkat pengetahuan yang baik tentang mobilisasi dini pasca section cesarean. Sikap ibu dalam mobilisasi dini pasca sectio cesarean di Ruag Dara RSUD Wangaya Denpasar sebagian besar yaitu 17 responden $(48,6 \%)$ memiliki sikap yang baik dalam mobilisasi dini pasca sectio cesarean. Tingkat pengetahuan yang baik tentang mobilisasi dini sebagian besar memiliki sikap yang baik dalam mobilisasi dini dengan persentase $34,3 \%$. Hasil analisis bivariat menggunakan uji Rank Spearman didapatkan hasil $\rho$ value $=0,000<\alpha=0,05$ maka Ho ditolak dan Ha diterima yang berarti terdapat hubungan tingkat pengetahuan dengan sikap ibu dalam mobilisasi dini pasca sectio cesarean di Ruang Dara RSUD Wangaya Denpasar.

\section{Saran}

1. Kepada institusi Pendidikan: hasil penelitian dapat digunakan sebagai referensi, selain itu dapat digunakan untuk mengembangkan ilmu pengetahuan dan wawasan mahasiswa mengenai tingkat pengetahuan dengan sikap ibu dalam mobilisasi dini pasca sectio cesarean.

2. Kepada peneliti berikutnya: hasil penelitian ini dapat digunakan sebagai bahan acuan untuk penelitian berikutnya, sehingga penelitian ini dapat digunakan sebagai gambaran untuk penelitian yang lebih lanjut tentang faktor-faktor yang mempengaruhi tingkat pengetahuan dengan sikap ibu dalam mobilisasi dini pasca sectio caesarean.

3. Kepada Pelayanan Kesehatan: hasil penelitian ini dapat digunakan sebagai masukan bagi tenaga kesehatan khususnya di ruang nifas, untuk meningkatkan derajat kesehatan ibu dan mempercepat pemulihan ibu pasca sectio sesarea.

4. Kepada Pasien: hasil penelitian ini dapat dijadikan sumber informasi dan pengetahuan bagi pasien atau ibu khususnya ibu postpartum akan 
5. pentingnya mobilisasi dini pasca sectio cesarean.

\section{UCAPAN TERIMAKASIH}

Peneliti mengucapkan terimakasih kepada pihak Rumah Sakit Umum Daerah Wangaya atas bantuannya, serta responden yang telah bersedia menjadi sampel penelitian ini.

Melakukannya Pada Wanita Usia 3050 Tahun Di Desa Joho Mojolaban. Surakarta. Universitas Muhamadiah Surakarta.

Depkes , R. (2013). Riset Kesehatan Dasar (RISKESDAS). Jakarta. Balitbang.

Dewi , P. (2013). Efektivitas Penyuluhan SADARI terhadap Tingkat Pengetahuan siswi SMA Negeri 2 di Kecamatan Pontianak Barat tahun 2013. Pontianak: Universitas Tanjungpura.

Guntur, F. (2006). Melawan Onkogen Erb B-2: Herceptin. Obat Kanker Payudara. Abocus . Bandung: ITB.

Indriyani. (2014). Buku Ajar Keperawatan Maternitas. Yogyakarta: Nuha Medika.

Indriyani, D. \&. (2014). Yogyakarta : Nuha Medika. Buku Ajar Keperawatan Maternitas.

Kemenkes , R. (2015). Kementerian Kesehatan RI Riset Kesehatan Dasar (RISKESDAS). Jakarta: Badan Litbang.

Kemenkes, R. (2013). Kementerian Kesehatan RI Riset Kesehatan Dasar (RISKESDAS). Jakarta: Badan Litbang Available :http://www.depkes.go.id (10 Juli 2019).

Kurniawati, D. (2015). Hubungan Pendidikan, Pengetahuan Dan Sikap Wanita Usia Subur (WUS) Dengan Pemeriksaan Payudara Sendiri (Sadari) Di Wilayah Kerja Puskesmas Dara Juanti Kabupaten Sintang Tahun 2015.

Manggala, A. (2013). Faktor-faktor yang mempengaruhi ibu postpartum pasca seksio sesarea untuk melakukan mobilisasi dini di rscm.

\section{DAFTAR PUSTAKA}

Ade,, N. (2017). Hubungan Pengetahuan dengan Sikap ibu post sectio caesare dalam mobilisasi dini di RSU Bahteramas Provinsi Sulawesi Tenggara.

Citra, S. (2016). Pengaruh Pendidikan Kesehatan Tentang Pemeriksaan Payudara Sendiri Terhadap Pengetahuan Dan Motivasi

Noorkasiani, Heryati dan Rita. (2012). Sosiologi Keperawatan. Jakarta: EGC.

Notoatmodjo, S. (2012). Promosi Kesehatan dan Perilaku Kesehatan. Jakarta: Rineka Cipta.

Nurzaid, R. (2019). Hubungan Tingkat Pengetahuan Dengan Pelaksanaan Mobilisasi Dini Pada Ibu Post Seksio Sesarea Di Bangsal Bedah Rs Pku Muhammadiyah Gombong.

Rottie, J. (2019). Pengaruh Mobilisasi Dini Terhadap Penyembuhan Luka Post Sectio Caesarea Di Irina D Bawah RSUP Prof Dr. R. D. Kandou Manado., 393-402.

Shadine, M. (2009). Penyakit Wanita. Jakarta: Keen Book.

Suryani , H. (2013). Hubungan Tingkat Pengetahuan Mobilisasi Dini Dengan Perilaku Mobilisasi Dini Ibu Postpartum Sectio Caesarea (Sc) Di Ruangan Sasando Dan Flamboyan RSUD Prof. Dr. W. Z Johannes Kupang., 53(9), 1689-1699.

Susiana, S. (2019). . Angka Kematian Ibu : Faktor Penyebab Dan Upaya Penanganannya.

Wawan, A., \& Dewi, M. (2011). Teori \& Pengukuran Pengetahuan, Sikap, Dan Perilaku Manusia. Yogyakarta: Nuha Medika. 